\title{
Discovery of Tanichthys albonubes Lin 1932 (Cyprinidae) on Hainan Island, and Notes on Its Ecology
}

\author{
CHAN Bosco Pui Lok ${ }^{1, *}$, CHEN Xiang-lin ${ }^{2}$ \\ (1. Kadoorie Farm \& Botanic Garden, China Programme, Lam Kam Road, Tai Po, New Territories, Hong Kong SAR; \\ 2. School of Life Science, South China Normal University, Guangzhou 510631, China)
}

\begin{abstract}
A wild population of the globally restricted and highly threatened freshwater fish Tanichthys albonubes Lin was recently discovered on Hainan Island, China. Prior to the present study, native populations were only known from isolated pockets in Guangdong Province of China and Quang Ninh Province of Vietnam; the Hainan record thus represents the first insular and southernmost distribution of this little-known species. Thus far it is known only from a single site in Hainan, despite repeated surveys of similar habitats throughout the island. The Hainan population occurs in a clean, sluggish coastal stream with abundant hydrophytes, and is sympatric with 20 fish species. Due to the unique geographic distribution of the Hainan population, and the conservation significance of the species, studies of its phylogenetic relationships with conspecifics populations elsewhere are underway. The exact locality of the newly discovered Hainan population cannot be revealed, but relevant government authorities have been notified and we are working to protect the site.
\end{abstract}

Key words: Tanichthys albonubes; Freshwater fish; New record; Ecology; Hainan; China

\section{唐鱼野生种群在海南岛的新发现及其生态资料}

\author{
陈辈乐 ${ }^{*},{ }^{*}$ 陈湘粦 ${ }^{2}$ \\ (1. 嘉道理农场暨植物园，香港特别行政区 新界大埔林锦公路; \\ 2. 华南师范大学 生命科学学院, 广州 510631)
}

摘要：于2007年在海南岛发现了国家II级重点保护动物唐鱼(Tanichthys albonubes Lin)的野生种群, 属种均为 海南新记录。该属全球只有两种, 种与种群间都呈间断分布, 对研究鲤科鱼类的系统发育及古地理等均有重要的 科研价值。由于早年过度采集作观赏鱼，加上珠三角地区的急速都市化发展，唐鱼曾被认为是野外已灭绝种。近 年被重新发现后, 迄今只知分布于广东省珠三角地区零散地点和越南广宁省下龙湾附近。海南岛是这个珍稀种首 次在亚洲大陆以外被发现的地点, 亦是唐鱼野生种群已知纬度最低的分布点。发现海南唐鱼的地点是一条低地小 河, 水质清澈, 水流缓慢, 水生植物茂盛, 与广东省报道的唐鱼生境类似。发现海南种群的小河鱼类丰富, 至今 记录有共生鱼类20种，包括大量掠食性物种，但唐鱼是该地的优势种之一。在不同月份都可以发现体长 $10 \mathrm{~mm}$ 下的仔鱼, 显示海南岛的唐鱼无明显的繁殖季节。海南岛跟亚洲大陆隔离历史长, 其唐鱼与亚洲大陆种群在形态、 分子水平上是否存在明显差异, 不同种群间的系统发育关系如何, 海南唐鱼的保护重要性是否更为突出, 是目前 正在研究的课题。

关键词: 唐鱼; 淡水鱼; 新纪录; 生态; 海南; 中国

中图分类号: Q959.4 文献标识码: A 文章编号：0254-5853-(2009)02-0209-06

The genus Tanichthys Lin 1932 is a primitive member of the speciose family Cyprinidae. Only two species, T. albonubes Lin 1932 and T. micagemmae
Freyhof \& Herder 2001, are known. A third, T. thacbaensis Nguyen \& Ngo 2001, from Yen Bai Province in northeastern Vietnam, was described in a

Received date:2009-02-24; Accepted date: 2009-03-17

Foundation item: Hainan biodiversity conservation project of Hong Kong Kadoorie Farm \& Botanic Garden

*Corresponding author(通讯作者), E-mail: boscokf@kfbg.org

收稿日期：2009-02-24; 接受日期：2009-03-17

基金项目：香港嘉道理农场暨植物园海南生物多样性保护项目 
Vietnamese publication (Eschmeyer \& Fricke, 2008), but the validity of this taxon remains to be studied.

Tanichthys albonubes was first discovered on White Cloud Mountain (Latitude ca. $23^{\circ} \mathrm{N}$; known as Baiyunshan in Chinese) in Guangzhou City (formerly Canton), Guangdong Province, South China (Lin, 1932), and was thought to be monotypic and endemic to the Pearl River Delta Region (Chen \& Chu, 1998). Because of its narrow global range and distinctive taxonomic position, the species is listed as a Class II protected animal in China's State Key Protected Animal List. Since its discovery, this brightly-colored minnow gained global popularity in the aquarium fish trade, and established feral populations have been reported from Colombia (Welcomme, 1988), Madagascar (Stiassny \& Raminosoa, 1994) and Australia (Corfield et al, 2008). However, $T$. albonubes has not been recorded in the wild since the 1980s, and the species was feared extinct due to a combination of over-collection by aquarists and, perhaps most important, large-scale urbanisation of the Pearl River Delta Region (Chen, 1936; Yue \& Chen, 1998; Wang \& Xie, 2004). In recent years, wild populations have been rediscovered, from a coastal stream draining into Halong Bay of Quang Ninh Province in northeastern Vietnam bordering China's Guangxi Province (Kottelat, 2001; Maurice Kottelat, pers. comm., 2009), and subsequently in isolated pockets close to its type locality and coastal Guangdong Province (Yi et al, 2004; information from websites).

\section{Methods}

At the invitation of Hainan Provincial Forestry Department, the first author and his colleagues have been conducting field surveys in an attempt to inventory biodiversity throughout Hainan Island and identify sites and species of high conservation value. Study sites include both nature reserves and unprotected forests, and special attention was paid to visit little known areas. Fishes were sampled by a combination of bankside observation, snorkeling, hand-netting and electrofishing. Water quality parameters were measured by a Hagen Master Test $\mathrm{Kit}^{\mathrm{TM}}$, and water temperature was measured by an aquarium thermometer.

\section{Results}

\subsection{The Hainan Tanichthys albonubes}

On 22 June 2007 we discovered a population of $T$. albonubes on Hainan Island. The site was far from any villages, and local inhabitants assured us that aquarium fishes were not kept nor had there ever been ornamental fish breeding farms in the vicinity. We therefore believe the population is of wild origin, and this is the first time the genus Tanichthys has been recorded outside continental Asia. Hainan Island has a latitude range between ca. $18-20^{\circ} \mathrm{N}$. All historic and current records of wild T. albonubes in mainland China and Vietnam have a latitude ranges between ca. $21-24^{\circ} \mathrm{N}$; the Hainan record therefore represents the southernmost distribution of this species. The global distribution of wild T. albonubes is illustrated in Fig. 1.

\subsection{Coloration and morphometrics}

A few specimens were collected for photography and morphometric measurements. The Hainan $T$. albonubes shows distinctive fin coloration in life; the dorsal, pelvic and anal fins being yellowish-orange in substitute of red as seen in wild fish from Guangdong or aquarium varieties. The dorsal and anal fins, and in some specimens also the pelvic fins have an intense distal orange band; an orange dorsal midline is always present (Figs. 2, 3). Preliminary examination of a limited number of specimens suggests that morphometric characters of the Hainan T. albonubes are within or close to the published ranges of Guangdong populations (Tab. 1).

\subsection{Ecological notes of Hainan Tanichthys albonubes}

Hainan T. albonubes occurs in a clean, meandering, sluggish coastal stream and its small tributaries. The stream has a sandy/pebble substrate, and fallen leaves sometimes accumulate on the streambed. Between April-August 2007 (i.e. the rainy season), the channel width was between $30-400 \mathrm{~cm}$ (in the main channel and the tributaries), and water depth was between $20-60 \mathrm{~cm}$. Water current ranged between $0.04-0.80 \mathrm{~m} / \mathrm{s}$. Water temperature in the open in August 2007 was $29.5^{\circ} \mathrm{C}$, and was $27-28^{\circ} \mathrm{C}$ under partial/complete shade in April 2008. The species forms shoals in backwaters and sluggish sections of the stream, and always stay close to some cover, most frequently among trailing vegetation along the banks. Various water quality parameters were measured at the downstream end of the Hainan $T$. albonubes site in the afternoon of 12 August 2007; the weather was sunny, with a daytime temperature of 35.2 ${ }^{\circ} \mathrm{C}$ and water temperature of $29.5^{\circ} \mathrm{C}$ in the open. The water tested was slightly acidic, soft, and unpolluted (Tab.2). 


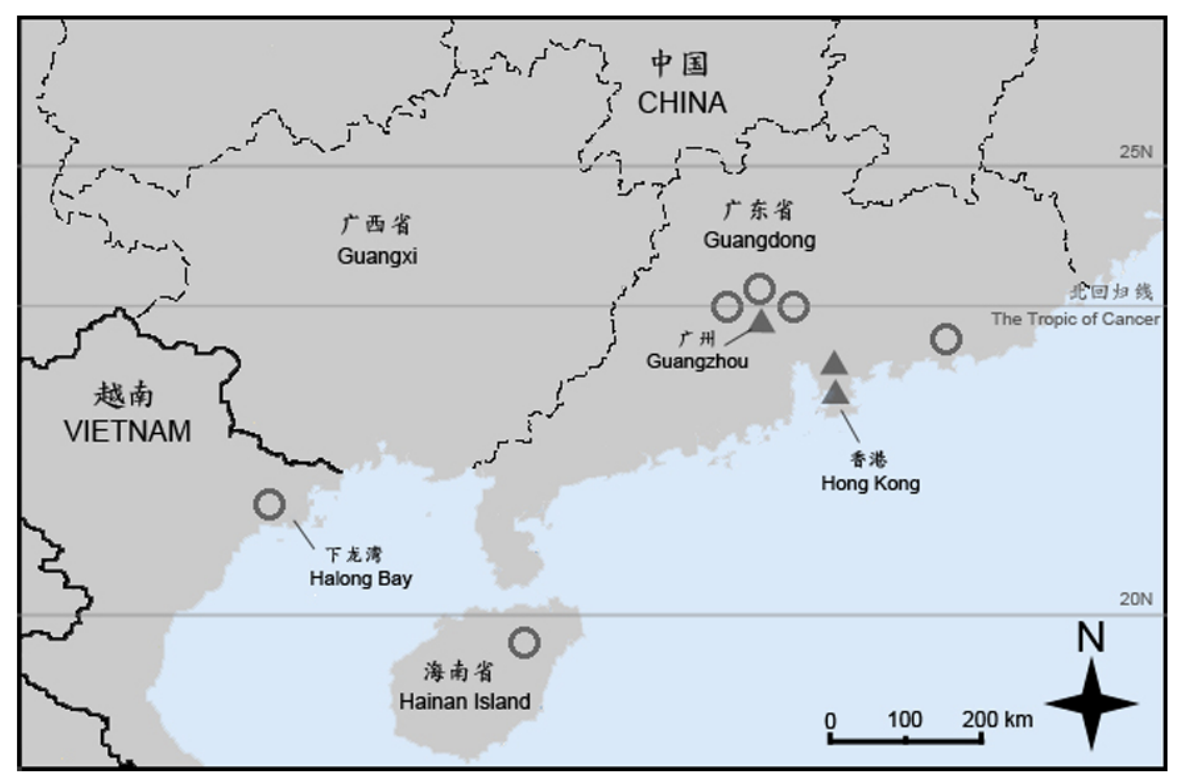

Fig. 1 Global distribution of wild Tanichthys albonubes Circles represent current sites, triangles represent historic sites.

Tab. 1 Morphometric data of wild Tanichthys albonubes from different localities

\begin{tabular}{|c|c|c|c|c|}
\hline \multirow[b]{2}{*}{ Characters } & \multirow[b]{2}{*}{$\begin{array}{l}\text { Hainan Island } \\
\qquad(n=3)\end{array}$} & \multicolumn{3}{|c|}{ Guangdong } \\
\hline & & $\begin{array}{l}\text { White Cloud } \\
\text { Mountain, } \\
\quad(n=11)\end{array}$ & $\begin{array}{l}\text { Conghua } \\
(n=40)\end{array}$ & $\begin{array}{l}\text { Shenzhen } \\
\qquad(n=3)\end{array}$ \\
\hline Standard length (SL) (mm) & $18.63-19.70$ & 21.00 (holotype) & $19.50-26.30$ & $26.00-30.00$ \\
\hline SL/body height & $3.85-4-15$ & 4.2 & $3.4-4.4$ & $3.7-3.9$ \\
\hline SL/head length & $3.42-3.59$ & 4.2 & $4.0-5.1$ & 4.3-4.5 \\
\hline Dorsal fin ray count & II - 6 & II -7 & III-6 & II - 6 \\
\hline Anal fin ray count & III- 8-9 & III- 8 & III-7-8 & III-8 \\
\hline Predorsal scale count & $15-16$ & “About 14” & -- & 15 \\
\hline Scale count along lateral midline & 32 & “About 30” & $30-32$ & $30-32$ \\
\hline Circum-caudal peduncle scale count & 12 & 14 & - & 14 \\
\hline Scale count between dorsal fin origin and pelvic fin origin & 8 & 7 & - & - \\
\hline Sources & This study & Lin (1932) & Yi et al (2004) & Ye \& Song (1991) \\
\hline
\end{tabular}

Tab. 2 Water parameters of the Hainan Tanichthys albonubes site measured on 12 August 2007

\begin{tabular}{ll}
\hline Water parameters & Reading \\
\hline $\mathrm{pH}$ & 6.4 \\
Hardness-GH $(\mathrm{mg} / \mathrm{L})$ & $<20$ \\
Hardness-KH (mg/L) & $<10$ \\
$\mathrm{NH}_{3}(\mathrm{mg} / \mathrm{L})$ & 0.1 \\
$\mathrm{NO}_{3}{ }^{-}(\mathrm{mg} / \mathrm{L})$ & $<5$ \\
$\mathrm{NO}_{2}^{-}(\mathrm{mg} / \mathrm{L})$ & 0.1 \\
$\mathrm{PO}_{4}{ }^{3-}(\mathrm{mg} / \mathrm{L})$ & 0.25 \\
\hline
\end{tabular}

The catchments area is a mosaic of secondary forest, shrubs and abandoned agricultural plots, and some reaches of the stream with $T$. albonubes have a complete canopy cover. The stream section with $T$. albonubes is approximate $1.5 \mathrm{~km}$ in length with an altitudinal range between sea-level to $36 \mathrm{~m}$ asl. No T. albonubes can be found upstream with steeper gradient and generally stronger current, and downstream where it flows through open, intensively-cultivated farmland with little bankside woody plants. Bankside trailing plants and hydrophytes are abundant; one characteristic plant along the stream bank is Pandanus gressitii, the spiny leaves usually form an overhanging dense mass in which $T$. albonubes take shelter. Tab. 3 is a checklist of hydrophytes recorded from the site. 
Tab. 3 Checklist of hydrophytes found in the Hainan Tanichthys albonubes site

\begin{tabular}{lll}
\hline \multicolumn{1}{c}{ Family } & \multicolumn{1}{c}{ Species } & \multicolumn{1}{c}{ Growth form } \\
\hline Acanthaceae & Gendarussa vulgaris & Emergent \\
Araceae & Colocasia antiquorum & Emergent \\
Commelinaceae & Commelina sp. & Emergent \\
Commelinaceae & Floscopa sp. & Emergent \\
Cyperaceae & Cyperus sp. & Emergent \\
Cyperaceae & Fimbristylis sp. & Emergent \\
Eriocaulaceae & Eriocaulon sp. & Emergent \\
Hydrocharitaceae & Blyxa japonica & Submerged \\
Lythraceae & Rotala rotundifolia & Emergent \\
Onagraceae & Jussiaea repens & Floating \\
Onagraceae & Ludwigia prostrata & Emergent \\
Pandanaceae & Pandanus gressitii & Emergent \\
Parkeriaceae & Ceratopteris thalictroides & Emergent \\
Pontederiaceae & Monochoria hastate & Emergent \\
Pontederiaceae & Monochoria vaginalis & Emergent \\
Scrophulariaceae & Limnophila sp. & Emergent \\
\hline
\end{tabular}

A total of 21 freshwater fish species, including $T$. albonubes, were recorded from the site. Other common native species include Parazacco (spilurus) fasciatus, Nicholsicypris normalis, Puntius semifasciolatus, Misgurnus anguillicaudatus, Oryzias curvinotus and $M a$ cropodus opercularis. Predatory species recorded were Anguilla marmorata, Clarias fuscus, Monopterus albus, Eleotris oxycephalus, Glossogobius giurus, Anabas testudineus, Channa gachua and Channa maculata. Invasive Gambusia affinis and Oreochromis sp. were present also but were scarce in the (mainly) shady stream section where $T$. albonubes is common. Fish life was abundant but $T$. albonubes is a co-dominant species despite being one of the smallest species in the fish community. Other (semi-)aquatic potential predators recorded include the water snakes Enhydris chinensis and Xenochrophis piscator, as well as the bullfrog Hoplobatrachus tigrina.

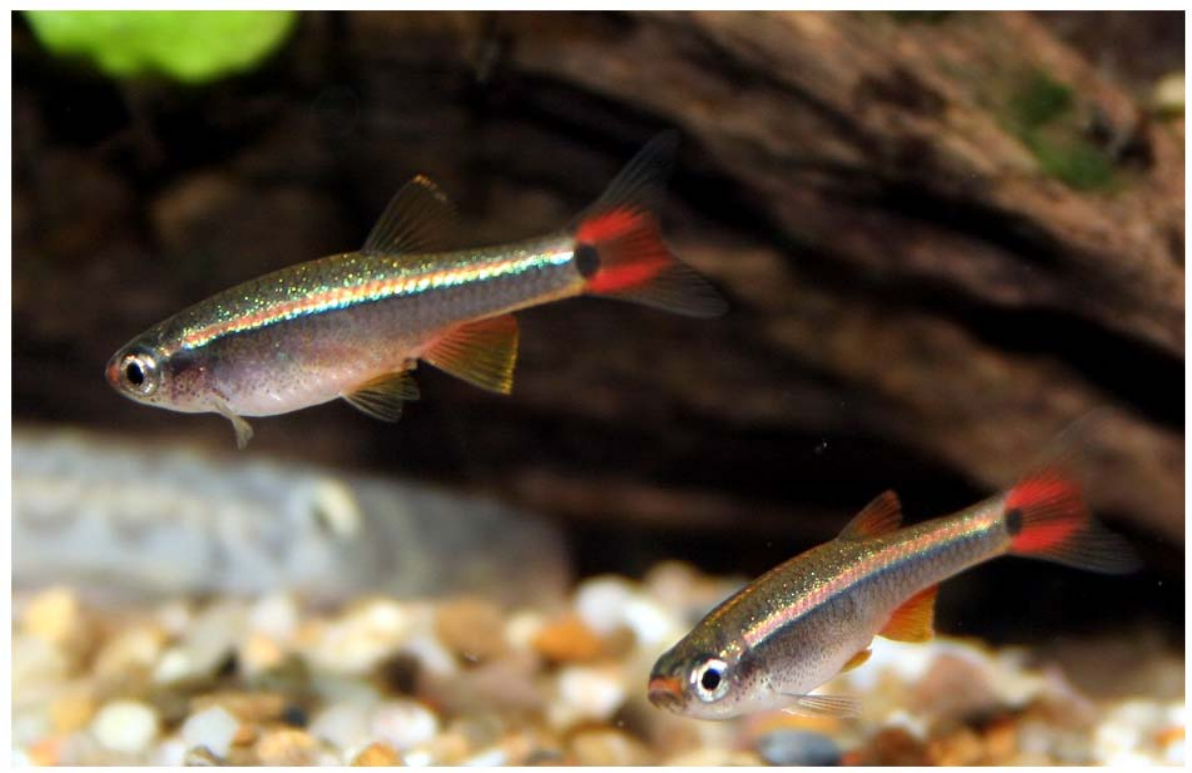

Fig. 2 Wild Tanichthys albonubes from Hainan Island, China (Photo: Bosco Chan)

Individuals less than $10 \mathrm{~mm}$ in total length could be observed in most months, suggesting the species may be able to breed year round in the warm climate of tropical Hainan Island. However, Hainan T. albonubes appears less tolerant to cold temperatures compare to at least aquarium-bred stock. Since September 2007 nine wild Hainan and a dozen of aquarium-bred T. albonubes were kept indoor in two unheated tanks side-by-side, but the Hainan T. albonubes started to die off during a prolonged cold spell in February 2008, when water temperature of the tank remained $<15{ }^{\circ} \mathrm{C}$ for over two weeks; the aquarium-bred stock was unaffected. Fish density in the wild appears normal up after the cold spell.

\section{Discussion}

Chen et al (2008) studied the molecular and morphological differentiation of "Opsariichthys bidens" complex in China, and the results suggested the Hainan population is genetically and morphologically distinct from mainland China populations. The Hainan-endemic species O. hainanensis Nichols \& Pope 1927 has been revalidated and is considered a basal member of the 


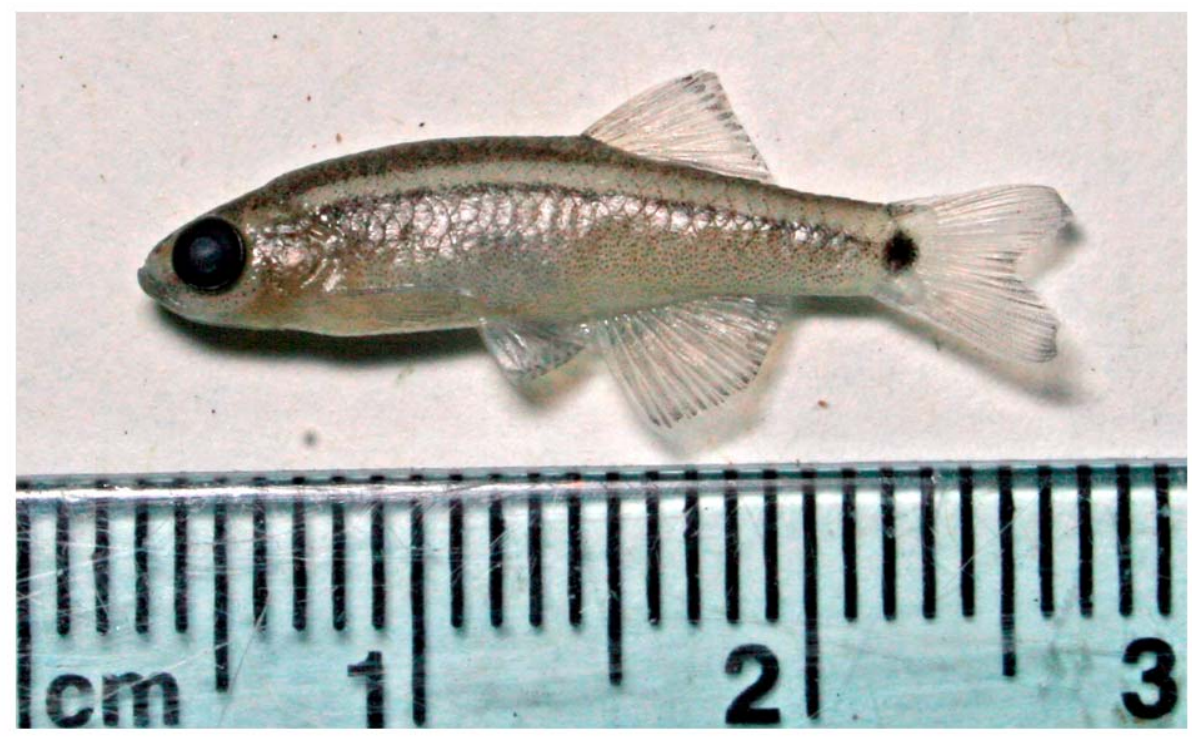

Fig. 3 Specimen freshly-preserved in 10\% formalin (Photo: Bosco Chan)

genus. The discovery of Hainan T. albonubes therefore has important implications for the studies on mechanism of population differentiation and on the origin of $T$. albonubes. This is the first time the genus Tanichthys has been recorded outside continental Asia. Hainan Island has a latitude range between $18-20^{\circ} \mathrm{N}$, and is more than $400 \mathrm{~km}$ south of any known sites where the species has been reported. The same distributional pattern has also been found in a genus of gomphid dragonfly (Zhang \& Tong, 2009) and a rare tree Bretschneidera sinensis (Zhang et al, 2007), both recently discovered on Hainan Island which were thought to have a predominately subtropical distribution.

T. albonubes has a disjunct distribution; the major range is close to the Tropic of Cancer north of Guangzhou City, another population was recently discovered in coastal Guangdong at Shanwei (information from websites), and there was a probably extinct population in nearby Shenzhen and Hong Kong, by the estuary of the Pearl River (Weitzman \& Chan, 1966; Ye \& Song, 1991). These, as well as the Vietnamese population and the Hainan population, may have been isolated genetically for a significant period of time. Genetic studies of their relationship and their relative conservation significance are needed urgently. Such work has been initiated in collaborations with researchers working on the Guangdong populations.
We tried to locate other T. albonubes populations in the neighbouring streams, but so far it can only be found in the site of original discovery, although similar habitats are located in the vicinity. To safeguard the newly discoveredHainan population, the exact locality of this discovery cannot be revealed, as hobbyists are always looking for "new imports" or "new varieties" in the aquarium trade, and a small, single population like the current Hainan Tanichthys would be particularly vulnerable to commercial collecting pressure. Nonetheless, relevant government authorities have been and/or will be notified and we are working to protect the site from potential destructive activities.

Acknowledgements: We would like to thank the Hainan Provincial Forestry Department for logistic support in fieldwork. Prof. David DUDGEON of The University of Hong Kong gave constructive comments on the first draft. Prof. YI Zu-sheng of Guangzhou University assisted in morphometric measurements of the Hainan specimens. Colleagues of the first author, Mr. Philip LO prepared Fig. 1; Mr. LU Gang identified the aquatic plants and, together with Mr. LEE Kwok Shing, helped in fieldwork. Dr. Maurice Kottelat kindly provided information on the Vietnamese Tanichthys. This study was funded by Kadoorie Farm \& Botanic Garden. 


\section{References:}

Chen IS, Huang SP, Jang-Liaw NH, Shen CN, Wu JH. 2008. Molecular evidence for genetic differentiation of the Opsariichthys bidens complex (Teleostei: Cyprinidae) in southern China around the South China Sea and the validity of Opsariichthys hainanensis [J]. The Raffles Bulletin of Zoology, Supplement Series No. 19: 215-223.

Chen TP. 1936. The Red-tailed Fish, Tanichthys albonubes Lin [J]. Lingnan Science Journal, Canton, 15(3): 431-437.

Chen YY, Chu XL. 1998. Danioninae [A]. In: Chen YY, Chu XL, Luo YL, Chen YR, Liu HZ, He MJ, Chen W, Yue PQ, He SP, Lin RD. Fauna Sinica, Osteichthyes, Cypriniformes II [C]. Beijing: Science Press, 49-50.

Corfield J, Diggles B, Jubb C, McDowall RM, Moore A, Richards A, Rowe DK. 2008. Review of the Impacts of Introduced Ornamental Fish Species That Have Established Wild Populations in Australia [M]. Prepared for the Australian Government Department of the Environment, Water, Heritage and the Arts.

Eschmeyer WN, Fricke R. 2008. Catalog of Fishes electronic version (updated 18 Dec. 2008). http://research.calacademy.org/ ichthyology/catalog/fishcatsearch.html.

Lin SY. 1932. New cyprinid fishes from White Cloud Mountain, Canton [J]. Lingnan Science Journal, Canton, 11(3): 379-383.

Stiassny MLJ, Raminosoa N. 1994. The fishes of the inland waters of Madagascar [A]. In: Teugels GG, Guégan JF, Albaret JJ. Biological Diversity of African Fresh- and Brackish Water Fishes [C]. Geographical overviews presented at the PARADI
Symposium, Senegal, 15-20 November 1993. Ann. Mus. R. Afr. Centr., Sci. Zool., 275: 133-148.

Wang S, Xie Y. 2004. China Species Red List Vol. 1 Red List [M]. Beijing: Higher Education Press.

Welcomme RL. 1988. International introductions of inland aquatic species [M]. FAO Fisheries Technical Paper, (294): 318.

Weitzman SH, Chan LL. 1966. Identification and Relationships of Tanichthys albonubes and Aphyocyprls pooni, Two Cyprinid Fishes from South China and Hong Kong [J]. Copeia, (2): 285-296.

Ye FL, Song BL. 1991. Danioninae [A]. In: Pan JH. The Freshwater Fishes of Guangdong Province [C]. Guangdong: Guangdong Science and Technology Press, 77-78.

Yi ZS, Chen XL, Wu JX, Yu SC, Huang CE. 2004. Rediscovering the wild population of white cloud mountain minnows (Tanichthys albonubes Lin) on Guangdong Province [J]. Zool Res, 25(6): 551-555.

Yue PQ, Chen YY. 1998. Pisces [A]. In: Wang S. China Red Data Book of Endangered Animals [C]. Beijing: Science Press, 68- 70.

Zhang HM, Tong XL. 2009. Trigomphus hainanensis spec. nov., a new species from Hainan, China (Anisoptera: Gomphidae) [J]. Odonatologica, 38(1): 67-71.

Zhang RJ, Ng SC, Xing FW. 2007. Bretschneideraceae, a New Record Family from Hainan Province, China [J]. Bulletin of Botanical Research, 27(2): 133-134. 